of fibres using phase contrast microscopy or by using $\mathrm{X}$-ray diffraction analysis.

A small cyclone size-separator was described by $\mathbf{H}$. Breuer. This prevents coarse dust from reaching a sample collected on a filter and thus the size distribution matches that of dusts recovered from the lungs of coal-miners. The dust admitted to the filter is about 50 por cent of the airborne dust at $1.5 \mu$ diameter, rising to 80 per cent at $1 \mu$; the acceptance curve is concave upwards and has, like the alveolar regions of the human lung, a small but definite acceptance beyond $7 \mu$. The performance is insensitive to differences between quartz, coal and shale dusts.

Tho rolationship betwoen concentrations measured by mass and those measured by number was diseussed by R. J. Hamilton, G. D. Morgan and W. H. Walton. The ratio of mass concentration $\left(\mathrm{mg} / \mathrm{m}^{3}\right.$ ) (measured after size selection by sedimentation with 50 per cent penetration to the sample at $5 \mu$ diameter), to number concentration, in thousands of particles more than $1 \mu$ diameter per $\mathrm{cm}^{3}$, ranged from 6 to 33 ; the spread was diminished when the size selection was made more rigorous, with a 50 per cent cut at $3 \cdot 5 \mu$, and this decreased the amount of dust collected by one-half to one-quarter. When the Breuer cyclone, described in the preceding paper, was used, the selected dust was about one-quarter that passing through the sedimentation instrument, which allowed a 50 per cent penetration at $5 \mu$. Various gravimetric sampling devices agreed with one another within about 10 per cent.
In another paper, H. Breuer described measurements of size distribution of airborne coal-mine dust. The peak size frequency of dust during coal-getting occurs between $4 \mu$ and $8 \mu$ for coal dust, below $3 \mu$ for dirt and between $2 \mu$ and $6 \mu$ for quartz. The finer dusts, rich in dirt, are associated with pneumatic stowing and blasting. The composition of the fine, or respirable, fraction of dust depends on the method of selection.

W. Walkenhorst emphasized that, since knowledge of alveolar deposition of dust is so uncertain, it is desirable to analyse the composition of a series of fractions of dust in size ranges below $10 \mu$, rather than taking a single arbitrary fraction of so-called respirable dust. He described a sedimentation classifier which distributed the particles, according to size, on a membrane filter. This allows analysis by optical microscopy, with determination of quartz content, in fractions down to $I \mu$.

The advantages of a personal dust sampler were stressed by R. I. Higgins and P. Dewell, who had made a small apparatus with $\mathrm{a}_{\text {a }}$ chest harness which weighed only $1.5 \mathrm{~kg}$. Size selection was achieved by a cyclone with 50 per cent penetration for particles a little below $5 \mu$ in diameter, for density spheres, the sample being collected on a filter. Motive power was derived from rechargeable nickel-cadmium cells and an electric motor driving a diaphragm pump equipped with a pulsation damper.

The Proceedings of the symposium will again be published by Pergamon Press as a book; it is hoped that this will appear in June.
C. N. Davies

\title{
CLEAN AIR
}

$\mathrm{C}$ LEAN air, in the true sonse of these words, does not imply simply smokeless air; there is very much more to it than this. There are other aggressive agents of air pollution the control and ultimate elimination of which are of as great importance to the health of the com. munity as the elimination of smoke, although the latter may often be the vehicle of their dissemination. These observations, and many other matters pertaining to the effects of the Clean Air Act and its impotus on progress in solving the problems of "the fog and filthy air", were well reviewed at the recent Clean Air Conforence convened at Eastbourne during October 26-29, 1965, by the National Society for Clean Air. Pre-prints of papers presented at this Conference, together with summaries released at the time, are now available (Pp. 155. National Society for Clean Air, Field House, Breams Buildings, London, E.C.4, 1965. 15s.). The subject of smokeless air has been briefly discussed in these columns before (Nature, 204,835 ; 1964); much has happened since then, particularly in respect to other hazards, notably sulphur dioxide, carbon monoxide, hydrocarbon exhaust fumes, grit and dust. In this connexion, a tightening up of the Clean Air Act (1956) would seem to be a practical possibility in the foreseeable future, particularly if coupled with the formulation of a sound national fuel policy, now receiving the attention of Mr. F. Lee, Ministor of Power, according to Smokeless Air (35, No. 134; Summer 1965. Pp. 255. National Society for Clean Air. 2s. 6d.).

The? presidential address to the Conferenco was delivered by Sir Alan Wilson. His main points were: a survey was carried out in fifteen pairs of housing estates of similar character except that one estate of each pair was subject to smoke control and the other was not; it was found that over 18 months, in the smoke-controlled areas, average concentration of smoke was 40 per cent less than in the areas not subject to smoke control (actual figures, $100 \mu \mathrm{g} / \mathrm{m}^{3}$ compared with $140 \mu \mathrm{g} / \mathrm{m}^{3}$ ). Although total smoko pollution had been considerably reduced, diminution in domestic smoke had been disappointingly slow; in
London, however, during the period when the relevant air-pollution measurements were made (1952-62), smoke was reduced by about 60 per cent-much better than the national average of only 35 per cent. Against this, sulphur dioxide emission had increased in the London region by about 80 per cent as compared with slightly less than 25 per cent in Britain as a whole. Sir Alan explained this by the fact that much more sulphur dioxide was dispersed into the upper atmosphero through high chimneys than smoke produced near ground-level. He went on to say: "Since one ton of low-temperature coke contains only about 75-85 per cent of tho sulphur in one ton of coal, and since 15 ewt. of coke produces as much heat as one ton of coal, replacement of coal by coke reduces the sulphur dioxide by about 40 por cent". Further, "Since there is no reasonable prospect . . . of reducing the total emission of sulphur dioxide throughout the country to negligible proportions, there is only one solution to the problem of smog, namely, town planning accompanied by the control of emissions by the regulation of fuel usage". This, of course, invokes the thorny problem of a national fuel policy with which, as already stated, the Ministry of Power is now grappling.

Most industrialized towns need not be dirty towns. This was the theme of three papers describing successes with smoke control. One of these is Manchester, the history of "some form of smoke control" of which extends over 120 ycars, according to Mr. J. Richards, senior public health inspector of that city. At the moment, 41.5 por cent of the total area of Manchester is subject to smoke control orders; it is hoped to make most of the eity smokeless by 1970. Another city is Sheffield, discussed by Mr. J. W. Batey, chief smoke inspector; as a result of the City Council's efforts, air pollution measurements between 1956 and 1964 reveal that smoke nuisance has been halved and the amount of sulphur dioxide in the air considerably reduced. 'The third 'success story' is Scunthorpe, where Mr. G. O. Allen, chief public health inspector, stated that although the town had not reached 
a "prosperous termination" of thoir desired end of air pollution, they were well on the way to their ultimate goal of "blue skies and pink lungs". Incidental to the problems faced is the question of solid fuel distribution and supplies; this was discussed by Mr. E. Otty, hoad of Special Projects Branch, National Coal Board, and Mr. W. H. Bourne, manager, National Fedoration of Coke Distributors' Associations.

One session of the Conforence was devoted to the subject of air pollution and mortality. Mr. A. J. Wicken, head of Health Surveys, AGB Research, Ltd., stated that the findings of a rocont survey in north-east England indicated that both lung eancer and bronchitis mortality are associated with ajr pollution. Speaking of odour control by catalytic combustion, Mr. E. Betz directed attention to the fact that many industrial effluents were not, as yet, covored by real legislation, it being left to local authorities to try to enforco production of clean and odour-free air; he claimed that, of available methods of removing organic fume nuisunces, catalytic combustion was the most efficient; this could solve odour problems in the chemical industry, in nitric acid manufacture and in the oven industry among many other applications. The Belgian method for dealing with road vohicle pollution was described by Mr. E. J. Coucke, director, Fund for Study and Research on Road Safety, Brussels. This method is based on a closely integrated system of technical inspection of motor vehicles, involving fifty inspoction stations, each equipped with a smoko-meter to measure diesel smoke density. Mr. Coucke went on to describe an intorosting experiment designed to reduco rate of emission of carbon monoxide by petrol engines, which was conducted with vehicles used by tho Paris Profecture of Police; this is essentially a matter of procise adjustment of carburettors ajmed at the systematic reduction of the production of this toxic gas while the motor is idling. His paper on Belgian practice in the matter of pollution of air by road vehicles is comprehensivo and worthy of study.

It was perhaps inevitable that in such a Conference as this, new horizons in domestic heating should command attontion, and the now familiar propaganda of what each of the competitivo fuel industries has to offer in various heating systems, and what the domestie consumer in the United Kingdom may look forward to in the near future to realize efficient, economical and completely smoko-freo warmth in the home, was characteristically conveyed by Mr. H. R. Brewster (Shell-Mex and B.P., Ltd.) repre. sonting oil intorests; by Mr. R. N. Bruce (chairman,
South Eastern Gas Board), concerned with gas (not excluding North Sea prospects); and by Dr. W. Reid (chairman, Northumberland and Durham Division, National Coal Board) in discussing steps being takon to promote higher standards of home heating apparatus, hence clean air, by production of adequate supplies of smokeless fuels, by stimulating design and production of new and, as near as possible, automatic appliances, and by district heating. The case for electricity was ably put by Mr. C. T. Melling (deputy ehairman, the Electricity Council).

Mr. J. Hodgson spoko on industrial aspects of dust collection and solection of proper equipment to deal with tho particular factory product or plant involved; his paper doalt, inter alia, with mothods of settling chambers, inertial collectors (cyclones), fabric collectors, wet colloctors and electrostatic precipitators. On the controversial subject of chimney heights, Mr. S. C. Beaumont (chief smoke inspector, Birmingham) roferrod to the Memorandum of Chimney Heights issued by the Ministry of Housing and Local Government which, although welcomed, did not provide all the answers to problems raised by conflicting interests in this matter, and which even the Clean Air Act failed to satisfy; he claimed that ". . . for reducing pollution from sulphur dioxide, tall chimneys apparontly were the present answer, but the best remedy would be the use of low-sulphur content fuels". The Conference conoluded by considering somo unresolved problems in air pollution. In this connexion there was an important contribution by Mr. F. E. Iroland, chief alkali, etc., works inspoctor of England and Wales, who described some of the difficulties still with us concerning nuisances relating to sulphuric acid, nitric acid, ceramic industrics, iron and steel, non-ferrous metals, metal recovery, and lime works; he added: "Tho search for solutions and improvements to industrial emissions continues unabated, both nationally and internationally".

The publicity afforded to the vital subject of clean air is in itself a healthy sign. The work of this Eastbourne Conference is a credit to all concomed. Britain is facing up to the problems involved in combating air pollution, from whatever source it may derivo, and it is encouraging to know that so many othor countriss are doing the same. The first congress of tho nowly formed International Union of Air Pollution Prevention Associations will be held in London during October 3-7, 1966; somo details of this desirable function are given in a recent number of Smokeless Air (36, No. 135; Autumn 1965. Pp. 13, 18. London: National Society for Clean Air. 3s.).

\section{REACTIVITY OF PHOTO-EXCITED ORGANIC MOLECULES}

$\mathrm{T}$ HE Solvay Institute for Chemistry was founded in 1913 , at a time when international conferences in science were comparatively rare. Since that time, as with other aspects of the rising tide of scientific knowledge, methods of communication have become much more numerous. Discussion meetings, conferences and symposia are being organized all over the world, to promote the advancernent of knowledge on broad or narrow fronts of science. At the present timo, those who are concerned with such organizing have to decide a number of questions, which it is useful to keep in mind when considering the outeome of any meeting of more than purely local appeal. When the primary object is to bring together and intograte rolated advances in different directions, as has always been the aim of Solvay conferences, the timing of the meeting, and the choice of those eligible to attend it, nocd to be planned with much greater care than is needed for more omnibus gatherings, at which the main object is to promote binary and ternary collisions of minds more or less at randorn, but in a favourable environment. If an inlegrating theme is aimed at, its selection must now also pay some regard to any related discussions at an international level, held or due to be held over a period which may extend ovor several years. Finally, the decision whethor to publish Proceedings of a conference, to be of real service to a much widor eirele of roaders than those who actually attonded it, calls for responsiblo judgment. This may not be easy, in view of the flood of scientific literature already available.

In the broad range of possible kinds of conferences, the pattern chosen by the Solvay Institute is one of the highest selectiveness in the choice of those invited to take part in the week's discussions. Only one or two pre-printed contributions wore considered each day. In the present instance these were by C. A. Coulson, R. Daudel, G. S. Hammond, E. Havinga, G. Porter, G. O. Schenk, G. M. J. Schmidt and N. C. Yang. The printed texts were not restricted in length, in order to 